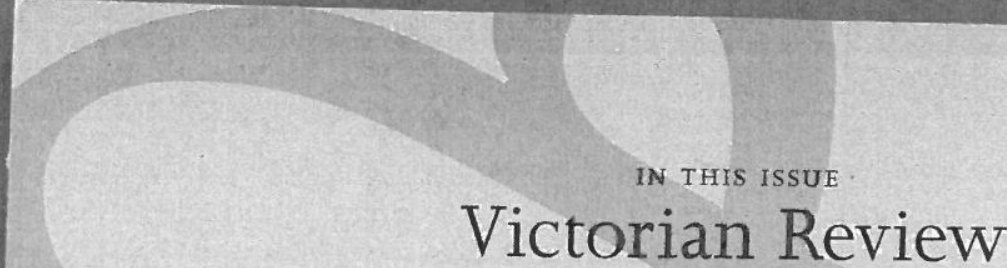

Volume 39 Number 2

Fall 2013

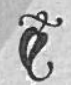

SPECIAL ISSUE: EXTENDING FAMILIES

Guest Editors: Kelly Hager and Talia Schaffer

FORUM: RECOUNTING THE FAMILY

Martha Vicinus \&̋ Richard A. Kaye है, Dara Rossman Regaignon

Maia McAleavey $\tilde{e}$ Marlene Tromp $\ddot{\ell}$ Ginger S. Frost

Elsie B. Michie $\widetilde{\ell}$ Valerie Sanders $\widetilde{\ell}$ Claudia Nelson $\widetilde{\ell}$ Eve M. Lynch

Karen Chase ש̋ Ivan Kreilkamp है Mary Jean Corbett

\title{
ARTICLES BY
}

Holly Furneaux ש̋ Matthew Ingleby ש̋ Vicky Simpson

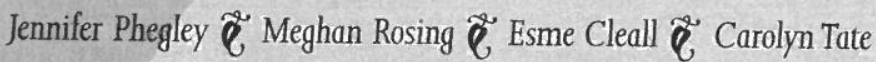

\section{REVIEWS BY}

Jessica Straley $\tilde{e}$ Ruth Bernard Yeazell ש̋ Eileen Cleere

Esther Godfrey ő Dara Rossman Regaignon हैं Susan David Bernstein 


\section{Chemistry versus Biology: Dickens, Malthus, and the Familiarized Doppelgänger}

MATTHEW INGLEBY

e

A QUEER VICTORIAN FAMILY CHRISTMAS

As HOLly Furneaux demonstrated in her groundbreaking Queer Dickens $A_{\text {(2010), we are not obliged to remain straightforwardly antithetical to }}$ the Victorian family. It is possible instead to secure a different perspective from which to re-envisage an institution that has hitherto been cast only in a conservative role, to showcase the plurality of unconventional familial relationships that can be found in nineteenth-century culture, despite the presence of the much-discussed but rarely manifest oppressive ideal. In taking this fresh approach, Furneaux's work has done much to show how Charles Dickens depicted the shifting and permeable actuality of the Victorian family, emphasizing the way his narratives persistently recognize the familial status of networks of chosen relationships, based on elective affinities rather than on biology alone. Indeed, as she shows, Dickens's novels frequently endorse the messy reality of extended families over the limited ideal of normative ones, revealing that the nuclear family unit is usually affectively insufficient, if not harmful. In so doing, Dickens encourages his readers to reconceive their idea of family. Dickens invites us, Furneaux insists, to consider families afresh, to revalue them, and to enquire of what they may consist and of whom they may include.

This article's focus is also Dickens. It shall, however, explore a text not discussed by Furneaux, The Haunted Man and the Ghost's Bargain (1848), the novelist's last annual Christmas book in the series of five that began with $A$ Christmas Carol (1843), the plot of which resembles that of the latter text in many ways. The most famous of the Christmas books does not feature greatly in Furneaux's argument either; when we consider the familial aspects of its plot, which are only rather ambivalently "queer," it is perhaps easy to see why. Ebenezer Scrooge is, promisingly, a bachelor, but the retrospective spectral visions he suffers lead him to regret rather than to celebrate his bachelordom, unlike Pickwick or the other happily unmarried men from Dickens's oeuvre whom Furneaux persuasively assembles. The miser is reinserted into an extended family at the end of the novella, but it is a blood relation (Fred, his nephew) with whom he spends Christmas Day, rather than 
with, say, the Cratchits, a counter-factual occasion that would have been a much more radical familial development. Even if the Cratchits' prize turkey has been supplied by a benevolent bachelor adopting the role of patriarch, in A Christmas Carol, everyone eats their festive dinners with their own family (by blood or conjugal tie). Thus, a form of biological determinism might be said to have the final word.

Though it is in many ways a sibling to A Christmas Carol, The Haunted Man is much less orthodox in the way it rethinks the Victorian family, and is indeed highly susceptible to the kinds of queer familial readings Furneaux has initiated, as a brief analysis of the story can show. The Scrooge figure, Redlaw, an unmarried chemistry lecturer, suffers from a severe depression originating in a traumatic social episode from his youth, when his fiance eloped with his best friend, who was in turn betrothed to Redlaw's sister. (This scenario suggests what we might call "quadrangular desire," in that it includes but also goes further than René Girard's three-way dynamic, involving in addition the complication of the implicit quasi-incestuous mimetic desire of the sister for her brother's object of homoerotic affection [Girard 1-52]). Entering into an apparently Faustian pact with a doppelgänger phantom, who offers to relieve him permanently of the memories that persistently refresh his sorrow, Redlaw agrees to pass on to all with whom he comes into contact this supernatural power of forgetting. Immediately upon the phantom's disappearance, Redlaw meets and feels an inexplicable and mutually undesired connection with an abandoned street child, who displays immunity to the chemist's new "gift," which the two of them subsequently "diffuse" around the city.

Rather than bringing peaceful oblivion to the various families Redlaw encounters, however, the power of forgetting sours the normative consanguineous and heterosexual relationships in which he intervenes: wives turn against husbands, sons against fathers, and so on. Before these relationships deteriorate any further, an antidote materializes in the form of a childless woman, Milly Swidger, whose interaction with the adversely affected characters returns their memories to them and, in turn, restores the affective bonds that had so suddenly been torn asunder. In the final pages, the bachelor Redlaw is reconciled with the Edward Longford, the son of his once-friend and once-fiance-becoming a benevolent figure by agreeing to support the young man financially so that he can marry and by paying for Edward's father's transportation to the colonies, which is presented as a second chance rather than a punishment, per se. The street urchin, meanwhile, is adopted by Milly, and the closing scene imagines a Christmas dinner-which Sally Ledger calls "a Bacchanalian feast of plenty" (Dickens 122) — at which all of the characters commingle, regardless of class distinction, family bonds, or blood ties. The new families that are constructed towards the end of the novella are barely permitted to settle before they are recombined in a single, transfamilial communal entity. The close of the text presents a series of familial adjustm of relationships biological deter! as a reversal, dc began. Rather, it a utopian meal liberated from family home. L from the insuf chain of huma

In its spotli६ for instance, Tł a genre in wh in an allegoric form. As Johr readers to fin didactic, from supernatural c just lubricate the "real" wc world, in wh binding, affe rather more as much abc the role of $n$ Tetterbys in of social rea Tetterby ann she might h that might 1 from an eve realism to $f$ to the fami

On the

the source radical pos attack on $t$ While the the memc to demon tion of th asserts th: than fixer both the 
uld have been a iits' prize turkey ole of patriarch, heir own family :rminism might

he Haunted Man is ly, and is indeed rneaux has initiz̧ure, Redlaw, an ;ion originating ıce eloped with : (This scenario ncludes but also , in addition the ire of the sister -52]). Entering om, who offers ntly refresh his les into contact the phantom's mutually undelays immunity uently "diffuse"

ımilies Redlaw mative consanres: wives turn e relationships I of a childless $r$ affected char$s$ the affective $s$, the bachelor is once-friend ig to support z for Edward's :econd chance ile, is adopted -which Sally t which all of iily bonds, or re end of the ined in a sinats a series of familial adjustments that resituate the nuclear family within a constellation of relationships that are based on mutuality and reciprocity rather than on biological determinism. The end of the novel, although it announces itself as a reversal, does not return us to the state of society in which the story began. Rather, it imagines a newly configured social order, metonymized in a utopian meal during which all of the characters of the story sit together, liberated from the spatial and social constraints of society and the nuclear family home. Unlike $A$ Christmas Carol, this ending moves quite clearly away from the insufficiencies of the nuclear family, to an endlessly expanding chain of human association.

In its spotlight on science, discussed below, and elaborate plot machinery, for instance, The Haunted Man can be seen as a precursor of speculative fiction, a genre in which philosophical ideas are explored through being enacted in an allegorical manner within what only appears to be a realist narrative form. As John Bowen says, this text's allegorical character has led some readers to find it intellectually contrived, over-ambitious, and confusedly didactic, from the time of its first publication onwards (76-77). Dickens's supernatural conceit of a contagious "gift" of memory-oblivion, after all, only just lubricates what is an abrupt and potentially unconvincing shift from the "real" world, grounded in sympathetic memory, to a distorted fantasy world, in which relationships suddenly sour as they come loose from the binding, affective ties of the past. But the structure of Dickens's text looks rather more sophisticated if we recognize its purpose in implying at least as much about the nature of family relationships as it bluntly states about the role of memory. Might not the dissatisfaction that mars the lives of the Tetterbys in the middle section of the novella be, in this light, the eruption of social realism within fantasy rather than the reverse? For example, Mrs. Tetterby announces at one point, while under the influence of the "gift," that she might have had a more attractive husband and fewer children (fantasies that might well have originated not through her supernatural forgetting but from an everyday sense of dissatisfaction). If we accept that the passage from realism to fantasy within the novel may be reversible, the text's relationship to the family appears to be queer indeed.

On the surface, then, the text's social parable suggests that memory is the source of affection within society, but The Haunted Man also implies a radical position on the nature of family relationships, mounting a covert attack on the essentializing notion of instinctive blood and conjugal affinity. While the central section of the book enacts a social experiment in which the memories of the participants are partially erased, it also might be said to demonstrate that blood is not thicker than water, entertaining a perception of the contemporary nuclear family as a living hell. Dickens's allegory asserts that the binds that tie us within families are socially mediated rather than fixed in nature and are maintained by active emotional attention, in both the present and the past. Thus The Haunted Man demonstrates - in the 
VICTORIAN REVIEW

manner of a reversible chemical experiment - the fragility of familial relations, the arbitrariness and therefore instability of consanguineous ties, and it hints at the alternative fates their oppressive presence often occludes. While Dickens's story shows that we all need a family, in so doing, it reconfigures that institution, stressing that the strength of familial ties inheres not in their biological ontology but in the social practices that constitute them. The text implicitly repudiates the idea of the nuclear family's sufficiency, showing not supersede them. together. It is no coinciden sex alone will not suffice to keep a family most powerful human agents within the that Milly and Redlaw, the two this text, Dickens indiates the potentian novella, are childless. Throughout nuclear family by demonstrating potentiality of human relations beyond the by choice or by fate, Motuded from natural reproduction.

urbanization nostalgia for a time before the industrial revolution and massalso gesturing implinship circles extended far beyond the nuclear unit, but text's evident dissatisfaction the might be said to look baction with the insufficiencies of the familial present familial models, Dickents as well as forwards. Appropriating residual utopian potential. In article, norm, Dickens opposes the biological determinism that characterizes the ticipates. It doppelgänger subgenre in which The Haunted Man uneasily parpopulation theory.

\section{DICKENS'S FAMILIARIZED DOPPELGÄNGER}

The doppelgänger motif in fiction that was popularized by E.T.A. Hoffmann conventionally entails a tragic end for the percipient; this is a trajectory adhered to in all of its most famous subsequent reincarnations.' By contrast, Dickens's appropriation of the trope unusually inscribes a comic conclusion. Rather than imprisonment or suicide, Redlaw is granted, like Scrooge, a second chance; he is resocialized and, moreover, re-familiarized: placed back within a network of quasi-familial relationships that direct his thoughts ble from the self-destructive, narcissistic end the appearance of the dou"family" into which Rortends. If one ignores the radical revisionism of the conservative move, effecting integrated, this might appear to be a rather mologically stable and absolute neglect of this text by decidable mode of domestic writing. The in part be accounted for by their inolars of the doppelgänger trope must finale as a disqualification freir identification of the comic subplot and "uncanny" subgenre (Royle $187-202$ ). Thoug been recognized as a definitively it is "one of the more remarkable explorations bowen has recently claimed,

double i

Dickens,

of the d

compari

Miller, $\mathrm{P}_{\text {i }}$

The Haunt

seem tha

doppelg:

But Tt

Gothic tr sympath motif, w tragedy a relations moderni conclusic distractic prize in 1 and its $p$ gates the appears i remedy $f$ only suic not in or the perpt pelgänge: appear to enacts a ized by $h$

While reproduc with chil, ure of the coincider represent which, th familial $r$ Rank, a c doppelgä] study on $t$ in his farr in the do strained $r$ extinctior 
lity of familial relaruineous ties, and it en occludes. While ing, it reconfigures inheres not in their tute them. The text ifficiency, showing 1 relations and cance to keep a family Id Redlaw, the two ildless. Throughout lations beyond the ıose who, whether ztion.

evolution and masshe nuclear unit, but is yet to come, the he familial present ropriating residual o as to suggest its ? remainder of this it characterizes the ed Man uneasily parnism of Malthusian

\section{İNGER}

y E.T.A. Hoffmann this is a trajectory ations.' By contrast, comic conclusion. ¿d, like Scrooge, a liarized: placed back irect his thoughts arance of the dourevisionism of the sear to be a rather hic into an episteestic writing. The ,änger trope must omic subplot and d as a definitively is recently claimed, me of the psychic double in nineteenth-century fiction" (76), in their discussion of duality in Dickens, Susan K. Gillman and Robert L. Patten neglect the representation of the double in The Haunted Man entirely, referencing the text only when comparing its treatment of memory with that of Little Dorrit (447). Karl Miller, Paul Coates, John Herdman, and Dmitri Vardoulakis do not mention The Haunted Man in their accounts of doppelgänger literature at all. ${ }^{2}$ It would seem that for these critics, a doppelgänger story with a happy ending is no doppelgänger story at all.

But The Haunted Man is not an artistic compromise, unsuccessfully grafting a Gothic trope onto a didactic romance about the importance of memory and sympathy with the poor. Rather, Dickens's appropriation of the doppelgänger motif, which retrieves the isolated percipient from the brink of individual tragedy and resituates him within fundamentally reconceived quasi-familial relationships, draws out and reflects upon an anxiety about reproduction in modernity that is implicit in all stories about the double. Dickens's comic conclusion and persistent focus on the family in this text's subplot is no mere distraction from or dilution of the Gothic isolation critics have tended to prize in the doppelgänger narrative. Rather, in its overt interest in children and its problematization of natural reproduction, the text critically interrogates the biological determinism that underlies the doppelgänger motif as it appears in the tales of Hoffmann and his literary successors, finding a social remedy for Redlaw's disorder where other writers would have prescribed only suicide or incarceration. Dickens's doppelgänger, then, is familiarized not in order to render the unheimlich heimlich but to suggest alternatives beyond the perpetuation of the nuclear family and death. By familiarizing the doppelgänger, by drawing him into familial social networks, The Haunted Man may appear to blunt the double's Gothic edginess, but at the same time, the text enacts a rupture in the nuclear family. The doppelgänger may be familiarized by his connection with family, but the family is thereby made strange.

While Dickens's treatment of the double associates doubling with natural reproduction by embedding it within a story that is elsewhere preoccupied with children, most stories about the doppelgänger tend to occlude the figure of the child, being nonetheless cryptically engaged with family. It is no coincidence that the lion's share of critical material regarding the cultural representation of the doppelgänger stems from the psychoanalytic tradition, which, through a hermeneutics of suspicion, interrogates the role of interfamilial relationships in the construction of individual psychology. Otto Rank, a colleague and friend of Sigmund Freud's, was the first to bring the doppelgänger into the field of psychoanalytical inquiry when he published a study on the figure in 1914. Freud cites this study when he develops the theme in his famous essay "The Uncanny" (1919). Both psychoanalysts recognized in the double the residue of a more primitive age, characterized by unrestrained narcissism, in which the self replicates itself as "insurance" against extinction. Just a few years earlier, Rank had published the first account of 
VICTORIAN REVIEW है Volume 39 Number 2

narcissism, which at its simplest libidinal level is the auto-erotic desire of the self for the self. It is not difficult to appreciate the relevance of this concept to understanding the self-reflexive literary phenomenon of the doppelgänger For the early twentieth century Viennese school of psychoanalysis, the motif of the double became associated in modernity with death, implicitly because of its root relation to unproductive narcissistic auto-eroticism.

A number of cultural studies of the doppelgänger are alert to the narcissistic, and therefore abnormally erotic, energies sublimated in its literary representations. For instance, in his discussion of the double in German literature, Andrew Webber quibbles with Robert Alter's designation of the doppelgänger "host" (or percipient) as sexless, arguing instead that the conventional doppelgänger's bachelor status evinces a pronounced form of "duplicitous" sexuality, which may not be expressed in sexual acts but is always disturbingly present:

It is in this sense that many of the Doppelgänger hosts might indeed be called sex-less, even as they are racked by sexuality. The Doppelgänger represents, but also appropriates and diverts, subjective desire. The Doppelgänger hero recurrently plays host to a sexual impostor. (Webber 13)

Whether or not we want to claim the doppelgänger myth as a site of queer sexual desire, a commensurable interpretation of the percipient's marital status can certainly be found in his childlessness. In foregrounding the idea of absolute replication, narratives about the appearance of exact doubles can be seen to announce an anxiety about the biological process of natural reproduction. The appearance of the double, then, may stand not only for quasi-narcissistic sexual desire but also for a fantasy about alternative reproduction. For Freud, the parent's affection towards his or her children, and therefore also the psychic raison d'être for reproductive desire, is itself "a revival and reproduction of their own narcissism, which they have long since abandoned" (Freud 91). If parenting thus involves a "revival" of the narcissism that is a crucial stage of child development but lies dormant in adulthood, and if the child's resemblance to its parents spurs them to nurture and protect it, does not the doppelgänger enact a fantasy of a form of more absolute replication than that which can be attained through biological reproduction? The tragedy that accompanies the appearance of the double in the bulk of its literary representations conservatively transforms the fantasy into a nightmare, however. In most cultural representations of the double, tragic mortality foils any utopia in which the narcissistic percipient is exempt from sexual reproduction. Not so in Dickens. While the doppelgänger tends to condemn its victims to death, Dickens squarely rejects this biological determinism both by letting the childless Redlaw survive and by granting him a new non-biological family.

In discussing the strange "interchangeability of haunted and haunter" and

highlighting Connor puts tale departs ity (5). Here is thoroughl a social para about such a initiates a pe in death or is with social i the "haunter himself. Ind as a second who materi the text's pr asserts, the him, the rea permits chi phantom di hands and 1 cry" that re belongs to theatre in $v$

A bui almo old $n$ years eyes, delic baby a cre who

A monster bosom no When the Redlaw re physiognc echo the ' In annour abandone reflection acknowle one who 
highlighting the odd role of an "intermediary" in The Haunted Man, Steven Connor puts his finger on one of the most intriguing ways in which the tale departs from the conventions of the doppelgänger mythos: its sociality (5). Here, haunting is contagious, because even though The Haunted Man is thoroughly concerned with the processes of the mind, it is very much a social parable and not purely a psychological one. While in most stories about such a phenomenon, the appearance of the double to the percipient initiates a period of ever-greater isolation from other human beings, ending in death or incarceration, in this tale, Dickens immediately confronts Redlaw with social interaction. Indeed, the phantom presents itself immediately to the "haunted man," demanding attention and distracting his thoughts from himself. Indeed, the text orchestrates the appearance of what might be read as a second (quasi-)doppelgänger to Redlaw in the form of the stray child who materializes at the very point the ghost leaves, and who functions as the text's primary site of moral (and implicitly political) anxiety. As Ledger asserts, the child is a confrontational figure within the text, and through him, the reader is "blamed for the toleration of a social environment which permits children to be neglected in this way" ("Christmas" 183). When the phantom disappears, leaving Redlaw looking "confusedly upon his [own] hands and limbs, as if to be assured of his identity" (344), he hears a "shrill cry" that replaces the words of the spectre still echoing in his head, a cry that belongs to a creature the chemist discovers behind a curtain in the lecture theatre in which he teaches:
A bundle of tatters, held together by a hand, in size and form almost an infant's, but, in its greedy, desperate little clutch, a bad old man's. A face rounded and smoothed by some half-dozen years, but pinched and twisted by the experiences of a life. Bright delicacy, - ugly in the blood and dirt that chal in their childish baby savage, a young monster, a child who had never been a child a creature who might live to take the outward form of man, but who, within, would live and perish a mere beast. (345)

A monster from the Malthusian imaginary, the child strikes fear into Redlaw's bosom not because of its otherness to him but because of its similitude. When the "savage" accompanies Redlaw in his distribution of the "gift," Redlaw repeatedly glances at its face and flinches at the emotional (if not physiognomic) resemblance to himself, a similitude that is surely meant to In the earlier, more exact "appalling copy" (339) of the doppelgänger. ${ }^{3}$ In announcing a "terrible companionship" (387) between Redlaw and the refleandoned child, Dickens appropriates the doppelgänger motif of selfacknoction and moves beyond its narcissism by forcing the percipient to one who ise his kinship not with one who looks exactly like him but with one who is repugnant and at first glance entirely other: the Malthusian 
VICTORIAN REVIEW है Volume 39 Number 2

surplus child. Through his connection to the child, the doppelgänger of

Dickens's tale unusually proves to be not so much an agent of death as a prophet, a vessel for moral enlightenment, like the ghosts of past, present,
and future in A Christmas Carol.

\section{THE MALTHUSIAN UNCANNY}

Malthus, who has recently begun to attract a great deal of critical attention in the field of nineteenth-century literary studies, has long been recognized by critics as a key bogeyman within Dickens's Christmas books, works which are held to oppose outright a Malthusian attitude to the children of the poor, exposing it as nothing more than a rationalization of heartlessness. ${ }^{4}$ Classically, the unredeemed Scrooge's chilling reference to the "surplus population" outs him as a reader of the second edition of the Essay on the Principles of Population (1803). As Ledger implies in her summative interpretation of the Christmas books, pointing to the similarities between A Christmas Carol and the lesser-known The Haunted Man, the latter in many ways echoes the former's anti-Malthusian sentiment ("Christmas" I82). At the final moment before the reversal of Redlaw's nightmarish "gift," after all, the Tetterbys seem to have converted to Malthusianism, announcing that "Poor people ... ought not to have children at all. They give us no pleasure" (394). This confession appears, symbolically, to be the threshold of familial dissociation, the point at which the parents themselves have internalized the political economist's message. Their deliverance from the poison of the "gift" is, most fundamentally, the reversal of a calamitous Malthusian drift in their thinking.

Though in a very broad sense, this summary of the novella's underlying anti-Malthusianism holds, it does not account for the more ambiguous role Of overpopulation anxiety in The Haunted Man. As we shall explore, this 1848 than has yet been appreciated the Malthusian dilemma far less dismissively economist, been appreciated, and indeed, appears to concede much to the "problem", the "problem" of the overproduction of children. While the ending of Dickens's novella, contra-Malthus, imagines social (and technological) escape routes from the destructive cycle of familial expansion and implosion the economist prophesizes, The Haunted Man is nonetheless suffused with Malthusian anxiety. The novel begins, after all, with Malthusian geographical commentary, dwelling upon the baldest proof of population expansion, the sprawl of the physical city itself, which surrounds the vault-like college in which Redlaw lives. Built initially in open space, the place is now "squeezed in on every side by the over-growing of the great city" (326), while inside, the shadows "released" by twilight gather "like mustering swarms of ghosts," taking "full possession of unoccupied apartments" (328) in a spectral shadow overpopulation.

The Haunted Man is more pervasively haunted by the ghost of Malthus through its figuration of the ever-expanding Tetterby family. While, on the surface the

depictiol story of 1 evinces $t$ is so ofte by the $\mathrm{G}$ When, fi speech," we can $n$ lost a chi may be $F$ of his far children of their I

Surely, th she retur "went thr Dickens s sister, Sa]

Sally's both a M ed in the The onor have faile on the $w$ tion, she remarkin radical lit industry George E be a curi that was tion of it: social cri text by $\mathrm{t}$ "dental ha her parer seen as a 
spelgänger of of death as a past, present,

cal attention 1 recognized works which ldren of the artlessness. ${ }^{4}$ .rplus popuit the Principles ation of the as Carol and he former's t before the em to have ught not to on appears, it at which 's message. :ntally, the

nderlying uous role this 1848 missively ch to the in to the Jickens's ie routes e econolthusian smmen: sprawl I which $\mathrm{d}$ in on de, the ghosts," pectral

urough ice the depiction of a large, Cratchit-like family acts as a comic counterweight to the story of Redlaw's misery, Dickens's treatment of the Tetterbys also persistently is so often the case in Dickens's texts, the that attend reproductive excess. As by the Gothic or tragic in the texture of sentimental or comic is shadowed When, for instance, Mr. Tetterby "seem [s] writing as much as in the plot. speech," after she casually invokes the idea dislike" his wife's "figure of we can read this as a kind of homage of sensitivity paid unborn" (355-56), lost a child (like Milly Swidger), but we cansitivity paid to those who have may be pregnant again, and the repetitive and of his family horrifies the over-burtive and seemingly endless expansion children are figured as surplus to rdened father. Indeed, even the present of their raucous behaviour suggests:

"Isn't it enough that your dear mother has provided you with
that sweet sister?" indicating Moloch; "isn't it enough that you
were seven boys before without a ray of gal, and that your dear
mother went through what she did go through, on purpose that
you might all of you have a little sister, but must you so behave
yourself as to make my head swim?" (351)

Surely, the "seven boys" whose raucousness so plagues their mother when she returns from shopping may themselves have been what Mrs. Tetterby Dickens suggests, may never have be what she really wanted: a girl. The boys, sister, Sally, but were only a means of objects of parental desire, unlike their Sally's nickna means to an end

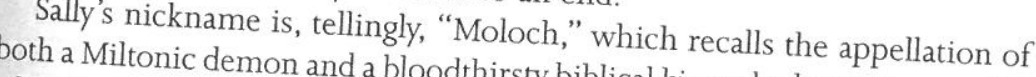
ed in the popular imagina bloodthirsty biblical king who becomes associatThe onomastic analogy here is subversively Malh of infants (D. Miller 140-45). have failed to address sufficiently. When Josephinusian, a complication critics on the way this text participates in tion, she notices but does not account for discourse about overpopularemarking in a footnote that Dicken " radical literature of the time, industry or capital, making the baby the sacrifice of infants to the Moloch of George Eliot" 230). The mock equatiolf Moloch" (McDonagh, "Murder in be a curious ino that was entirely dismindeed for a straightforwardly anti-Malthusian text tion of its rhetoric is surely of the overpopulation dilemma, as the implicasocial crime through unproductive child is, in some sense, a perpetrator of text by the child's eternal teething, over-consumption-symbolized in the "dental haunting" (Connor I). Thing, which has been described as a kind of her parents' previously ungilded This final child, the first "ray of gal" to grace seen as a kind of ruthless monarch to the seemingly surplus boys whom she 
VICtORIAN REview है Volume 39 Number 2

joins. One of her brothers, her chief baby-sitter, Johnny, though devoted like a cult-member to his task, does appear to be being sacrificed on the "insatiate altar" of his little sister, as he is forced to attend to her constantly, like a slave:

Wherever childhood congregated to play, there was little Moloch making Johnny fag and toil. Wherever Johnny desired to stay, little Moloch became fractious, and would not remain. Whenever Johnny wanted to go out, Moloch was asleep, and must be watched. Whenever Johnny wanted to stay at home, Moloch was awake, and must be taken out. (349)

Though the logic of his narrative finally rejects the negativity invested in the figure of the child by overpopulation theory, Dickens is in the characterization of Moloch nonetheless making a dark Malthusian joke. Without endorsing the Puritanical pessimism of Malthus's political economy, Dickens acknowledges that in over-large families, the extra child becomes a figure of doom, acting like a slave-driver to the rest of the family, demanding constant attention from the other children in the house, and indeed, driving out to work brothers and sisters that are not a great deal older than they are. $^{5}$ At one point, Mrs. Tetterby chides her son Johnny, warning him that he might drop his little sister on her head and thus kill her: "Johnny, don't look at me, but look at her, or she'll fall out of your lap and be killed, and then you'll die in agonies of a broken heart, and serve you right" (356). Mrs. Tetterby's melodramatic injunction, though comic in its ostensible function, nonetheless moots a fantasy of contagious infant mortality well before the "gift" leads her and her husband to the brink of Malthusianism. Far from the Malthusian dilemma being anterior or Other to the imaginative world of the ever-extending nuclear family, it lies just beneath the surface of the everyday Tetterby family scene. Malthus is not introduced supernaturally into the family circle through the artificial diffusion of the "gift" of Redlaw; rather, he has been there all along.

\section{REDLAW AND THE LAW OF NATURE}

Dickens proposes two solutions to the Malthusian dilemma, one being an explicit social solution, and the other, an implicit technological one. If the figure of Malthus can be said to haunt the text through the implicit rejection experienced by the abandoned child-monster, the seven Tetterby non-girls, and Philip Swidger, superfluous because he is eighty-seven years old, Dickens counters the economist's ideas most strongly by demonstrating that a number of characters have more affection to give than their nuclear family alone can absorb. Milly, for instance, acknowledges palpable absences in her emotional life and admits to an excess of affection to bestow as a result of mourning the "little dead child that [she] had built such hopes upon, and that never breathed the breath of life" (406). When she adopts the abandoned child at the end of the novella, the novel endorses a redistributive economics of family

relatio

be add

parent

would

be an

neutrá

an ins

the pl

that"

more

image

worlc

the bo

broac

sibili

W

logic

motl

norn

won

debi

pow

essa

the :

boy,

By $c$

a ki

chil

fam

pro

$\operatorname{Rec}$

the

pay

"rer

ans

do

wh

act

ics

bis

nc

ne

wi 

be addressed through the social technology of surrogacy, or non-biological parenting, which itself cancels out the affective surplus of the childless would-be parent. The surplus of unnecessary children is thus revealed to be an illusion, the product of an incomplete perspective, as it can be easily neutralized by the surplus of affection that overflows from those who have an insufficiently small family or none at all. It is no coincidence that when the phantom doppelgänger delivers to Redlaw his final prophetic message, that "open and unpunished murder" (387) in the city's streets would be more tolerable than the neglect of the children, he repeatedly invokes the image of the "barren wilderness." For Dickens, the prospect of an empty world is far more terrifying than one characterized by overpopulation, and the barrenness of being without affective obligations (be they parental or, more broadly, social) is at least as much a cause for concern as the abstract possibility of a planet full of Tetterbys.

While Milly's adoption of the street urchin does allow her to bypass biological maternity, it might be argued that when she becomes his surrogate mother, Dickens affirms less a reconfiguration of family relations than a normative representation of the neediness and incompleteness of childless women. But this view implicitly renders Milly's childlessness more socially debilitating than the narrative itself allows and plays down the enormous power for good that Milly wields over all the other characters. In that unnecessarily suspicious reading, moreover, the motivation of Milly's adoption of the stray child becomes more relevant than the action of her acceptance of the boy, which seems to me to reverse the relevant hierarchy of critical interest. By contrast, to my mind, Dickens chooses not to emphasize the adoption as a kind of imperfect substitution of the biologically for the socially parented child but instead celebrates the insertion of a surplus child into a childless family as an affective exchange that magics away what seemed an insoluble problem in an instant.

While Milly's adoption of the abandoned child is radical, more so is Redlaw's decision to take responsibility for the welfare of Edmund Longford, the child of his treacherous once-friend and the woman who jilted him. In paying the "very little money" required for the latter's transportation and "remov[ing] him to some distant place, where he might live and do no wrong, and make such atonement as is left within his power for the wrong he has done" (404), the childless Redlaw actively appropriates for himself a son whose own blood relations have disappointed him. In this interventionist act of surrogacy, the text goes beyond the redistributive affective economics of Milly's adoption of an apparently relation-less child and suggests that biological familial relations can in some cases be superseded by stronger non-biological ones. Edmund's biological father is removed to make way for a new non-biological paternal figure, forging in the process a relationship that will be as mutually beneficial as the previous one was mutually unsatisfying. 
In the adoptions that occur towards the end of the novella, Dickens gestures towards a society in which sympathy has been liberated from its confines within blood and sexual relationships, a gesture that is concretized in the utopian Christmas dinner with which the text concludes. The scene draws liberally on nostalgia for a pre-urbanized, pre-industrialized era before ties completely absency of the nuclear unit, rendering Malthusian anxieare mingled and merged in a previously separated individuals and families the surplus population site in which people is treated as cause for counting the numbers for unmitigated celebration, the only worry about to be believed: "Thers being that they might seem to the reader too large children, doubts, in the distempt to state them in round numbers might engender together so mantrustful, of the veracity of this history" (407). Gathering extends the family soxtras, to whom we have not been introduced in the story, and qualitative so as to effect its metamorphosis in both quantitative ships of the nexclusively centred upon the core relationfor perhaps the frrst fime attention of these guests can be channelled there convened. Appropriating the other friends or strangers who are it, Dickens's text imathe Malthusian position before repudiating demonstrating that "prely attends to anxieties about overpopulation by rather an surplus" is no problem at all, but is institution invitation to reinvent the family as a more flexible and capacious Dick "socialnus envisages.

Dickens's "social” solution to Malthus's dilemma of overpopulation-the sharing or redistribution of affective labour and duties of care-is more or less figured explicitly in the text, but another more latent rebuttal is concealed in the symbolic associations of Redlaw's career as a chemist. While we can easily see the social amelioration of the end of the Dickens novella as a challenge to the pessimistic biological determinism of Malthus's model, the text's more blatant concern with a different scientific discipline, chemistry, also engages less obviously with the "problem" of overpopulation. Redlaw's ingecialism as a chemist has been insufficiently addressed by critics, a striking critical blind spot given the prominence of the figure of the chemist Sandman" and Stever doppelgänger narratives, notably Hoffmann's "The Redlaw's theories of consciousness waterial conservation as an analogy for theories of in this regard (Bowen vocation as a metaphor textualize it more literally something else, like Bowen, might we not con-

within the field of 184 os chemistry itself?

The 1840 s was a decade in which chemistry was continually in the public eye and at the centre of debates about overpopulation. This is in large part

due to the pra challenged $\mathrm{p}$ increased cro time, Justus I the mineral $c$ cussed. In pav ameliorated $\mathrm{fi}$ scientific wor the writings ( public sphere economic ro] Wolfgang Khr istry was exp destructive " $n$ light of this st pessimism, th each other's v August 1851 re wish I could b and in whom

Though Li Dickens's eyes ist of note at $t$ vation at least . Boussingaul in England aln started the mc scientific com factory in 184 nearby sugar 1 key ingredien proponent of and it was for to the man in which praised working-class Henson, that liberal-progre that chemistry social (and b' amelioration (

Returning 1 might be said social restruct 
1, Dickens d from its oncretized The scene era before ian anxie$\mathrm{d}$ families in which excess of orry about : too large and with engender Gathering a the story, lantitative e relationhannelled 5 who are pudiating ulation by all, but is capacious

ion-the ; more or al is conWhile we ivella as a lodel, the hemistry, Redlaw's s, a strikchemist n's "The tation of :ories of xception cientific not conboratory

e public rge part due to the practical strides being accomplished in agricultural science, which challenged pessimistic predictions of resource finitude by promising vastly increased crop yields. The discoveries of the most famous chemist of his time, Justus Von Liebig, about the oxygen-carbon cycle and the impact of the mineral content of soil on plant growth were well publicized and discussed. In paving the way for the development of artificial fertilizers, which ameliorated food scarcity and therefore prevented population depletion, the scientific work of Liebig countered Malthusian logic at least as effectively as the writings of a number of more obviously anti-Malthusian figures in the public sphere. Indeed, Liebig was himself very much aware of the politicaleconomic role of his endeavours in the field of chemistry. According to Wolfgang Khron and Wolf Schäfer, Liebig's turn towards agricultural chemistry was explicitly motivated by a desire to disprove the necessity of the destructive "moral hazard" of Malthus's model (27-52). It is no surprise, in light of this shared scepticism about the population theorist's deterministic pessimism, that Dickens and Liebig were aware of each other and admired each other's work. A note Dickens sent to Doctor Sheridan Muspratt on 24 August 1851 reveals that he admired the chemist and desired to know him: "I wish I could be there to meet Baron Liebig, one of the greatest men in Europe, and in whom I am (as who is not?) most strongly interested" (Letters 47I).

Though Liebig, as the leader of progressive science at the time, was in Dickens's eyes one of the "greatest men in Europe," he was not the only chemist of note at the time, and indeed, Britain was in the I840s a centre of innovation at least as significant as Germany. As Folke Dovring says, "Around 1840 . Boussingault in France, von Liebig in Germany, and [John Bennet] Lawes in England almost simultaneously found formulas for chemical manures that started the modern fertilizer industry" (Dovring 654). Lawes, who combined scientific comprehension with an entrepreneurial mind, opened a fertilizer factory in 1843 on Deptford Creek, London, where the waste products of nearby sugar refineries could be utilized as a cheap source of phosphate, a key ingredient in the nutrient cycles (Thompson). A philanthropist and proponent of social reform, Lawes provided model villages for his workers, and it was for this rather than for his chemistry that Dickens wrote a paean to the man in All theYear Round entitled "The Poor Man and His Beer" (1859), which praised the chemist for his pragmatic and generous attitude toward working-class drinking. It seems reasonable to extrapolate, following Louise Henson, that Dickens saw chemists such as Lawes and Liebig as part of a liberal-progressive alliance in which he himself participated, recognizing that chemistry was engaged in resisting social theories that left no role for social (and by extension, technological) agency in the cause of human amelioration (Henson 4).

Returning to The Haunted Man with this in mind, we can see that Dickens might be said to undermine the Malthusian hypothesis not only with a social restructuring but also with the hint of an additional technological 

Solution to the problem of overpopulation. When his doppelgänger lambasts
Redlaw as the "growth of man's presumption" (388), thus criticizing the not renounce his profession, drowning his bificant that the scientist does status of the surrogate son, himself also his books like Prospero. Indeed, the science is part of the promising new world of the novella rather than a negative aspecld ushered in by the comic end dinner, in the old college hall, more aspect of Redlaw's past. The Christmas sociality of the academic world, associating ins to emphasize the potential human happiness rather than the isociating it with the communal pursuit of endeavour. Rather than punishing Redled narcissism of abstract intellectual alchemical project, as Stevenson might be said lone and self-aggrandizing Dickens instead leaves open the possibility thaid to do in Dr. Jekyll and Mr. Hyde, will include the better use of his scientific that the chemist's redemption familiarized Redlaw may indeed becontific knowledge. The redeemed, renear-namesake, Lawes, dedicating himself something like his philanthropic publically recognized) goal in chemistry the most socially engaged (and increase crop yields in order to prove Malthus's gime: discovering how to

From the heavy enormity of Moloch to the gloomy predictions wrong. from Milly's childlessness to Mrs. Tetterby's the diminutive size of Mr. Tetterby, out the text covertly associated with by contrast associated with radical changeabilitye determinism. Chemistry is are first introduced to Redlaw, Dickens the elements he mixes and separates at will in the chemist's mastery over

at will in his isolated study: part laboratory,-for he in his inner chamber, part library and a learned man in chemistr, as the world knew, far and wide, hands a crowd of aspiring ears and teacher on whose lips and had seen him there, upon a winter eyes hung daily, - who that his drugs and instruments anter night, alone, surrounded by lamp a monstrous beetle and books; the shadow of his shaded of spectral shapes raised the wall, motionless among a crowd the quaint objects around him; the flickering of the fire upon reflection of glass vessels that held liquids), phantoms (the like things that knew his power to liquids), trembling at heart back their component parts to fire ancombine them, and to give seen him then, his work done, and he vapour; - who that had before the rusted grate and red fame pondering in his chair if in speech, but silent as the dead, moving his thin mouth as man seemed haunted and the chamber not have said that the

(325-26)

Dickens might be seen to of biology with the agency of the chemist, the power to combine and recombin the latter discipline a confidence about er 
umbasts

ing the st does sed, the ms that aic end ristmas Jtential rssuit of llectual ndizing Mr. Hyde, mption ned, rethropic ed (and how to ; wrong. Tetterby hroughlistry is hen we sry over

in reimagining the family. Like atoms, he suggests, human beings are not deterministically confined within the context in which we find them but can be mobilized and redistributed, to the mutual benefit of all. Unsatisfactory biological relationships, such as that of the Longford father and son, can be superseded by newly forged non-biological ones in a form of social alchemy. Drawing out the scientific in the metaphor of "elective affinities," which Goethe first used to describe "kindred of choice," and which Furneaux has successfully revived to describe Dickens's other queer families, The Haunted Man deserves to be recognized as a sustained, imaginative response to the biological determinism that is both the implicit foundation of Malthusian theory and the implicit anxiety that lies behind the doppelgänger trope.

Notes

Hoffmann's "The Sandman" (1817), which features strongly in most accounts of the doppelgänger, prescribes suicide for Nathaniel, the figure who perceives the identicality of the double characters, Coppelius and Coppola. Edgar Allan Poe's "William Wilson"( 1839 ) and Robert Louis Stevenson's Dr. Jekyll and Mr. Hyde (1886) both end in murder-cum-suicides, while Fyodor Dostoyevsky's The Double: A Petersburg Poem (1846) closes in mental collapse, and Nabokov's Despair (1936) finishes as the main character is about to be captured by the police, after a disastrous murderous escapade.

2 In their critical accounts of the double in literature, John Herdman and Paul Coates both suggest that the general craze for duality was most pronounced both during the Romantic period, at the beginning of the 1800 , and then again during the fin de siècle, but that it encountered a lull in the middle of the nineteenth century.

3 "Three times the Chemist glanced down at his face, and shuddered as it forced upon him one reflection .... At each of these three times, he saw with horror that, in spite of the vast intellectual distance between them, and their being unlike each other in all physical respects, the expression on the boy's face was the expression of his own ... from that, to the child, close to him, cowering and trembling with the cold, and limping on one little foot, while he coiled the other round his leg to warm it, yet staring at all these things with that frightful likeness of expression so apparent in his face, that Redlaw started from him." (373-74) See John Schad (79-92) for a discussion of Dickens's ambivalent approach to family likeness and his emphasis on similitude of facial expression rather than facial feature.

4 Malthus has become a figure of increasing importance to scholars of nineteenthcentury literature. Karen O'Brien, for instance, has analysed Jane Austen's treatment of widows and spinsters in terms of Malthusian surplus, and Thomas Pfau has resituated Wordsworth's The Prelude similarly, while Josephine McDonagh has contextualized the anxiety that surrounds the figure of the Victorian child in terms of economically mediated debates about overpopulation.

Johnny is not the only one who is being sacrificed on Moloch's altar. The oldest boy, Master Adolphus, has also been sent out to work too young, as his tendency to carry a "prismatic comforter" around him displays. The depiction of Moloch's role in inviting the quasi-parental sacrifice of her siblings' childhoods is particularly extreme version of something Dickens returns to time and again in his fiction, from the uncomplaining Amy's motherliness to her family in Little Dorrit to the more vocal and resistant Caddy Jellyby in Bleak House. 


\section{VICTORIAN REVIEW ש̋ Volume 39 Number 2}

6 In Hoffmann's tale, the double character, Coppelius/Coppola is an alchemist, while in Stevenson's novel, Jekyll finds a potion that enables him to split in two, that is conducted in a laboratory not unlike the spaces available to Redlaw in the college in which he resides.

\section{Works Cited}

Bowen, John. "Uncanny Gifts, Strange Contagion: Allegory in The Haunted Man." Contemporary Dickens. Ed. Eileen Gillooly and Deirdre David. Columbus: Ohio UP, 2008. 75-92. Print.

Coates, Paul. The Double and the Other: Identity as Ideology in Post-Romantic Fiction. New York: St. Martin's Press, 1988. Print.

Connor, Steven. "Dickens, the Haunting Man." Literature Compass 1.6 (2003): I-13. Web. 3I Mar. 20I2.

Dickens, Charles. "The Haunted Man and the Ghost's Bargain." A Christmas Carol and Other Christmas Books. Ed. Robert Douglas-Fairhurst. Oxford: Oxford UP, 2006. 323-408. Print.

- The Letters of Charles Dickens, 1850-52. Vol. 6. Oxford: Clarendon Press, 1988. Print. "The Poor Man and His Beer." All The Year Round 30 Apr. 1859: 13-15. Print.

Dovring, Folke. "The Transformation of European Agriculture." The Cambridge Economic History of Europe. Vol. 1. Ed. Edwin Ernest Rich. Cambridge: Cambridge UP, 1965 604-72. Print

Dostoyevsky, Fyodor. The Double: A Petersburg Poem. 1846. Notes from Underground and The Double. Trans. Ronald Wilks. London: Penguin, 2009. Print.

Freud, Sigmund. On Narcissism: An Introduction. Ed. Joseph Sandler, Ethel Spector Person, and Peter Fonagy. London: Karnac Books, 2012. Print.

Furneaux, Holly. Queer Dickens. Erotics, Fomilies, Masculinities. Oxford: Oxford UP, 2010. Print.

Gillman, Susan K., and Robert L. Patten. "Dickens: Doubles: Twain: Twins." NineteenthCentury Fiction 39.4 (Mar. 1985): 441-58. Print.

Girard, René. Deceit, Desire, and the Novel: Self and the Other in Literary Structure. Trans. Yvonne Freccero. Baltimore: John Hopkins UP, 1976. Print.

Henson, Louise. "'Phantoms Arising from the Scenes of Our Too-Long Neglect': Charles Dickens, Victorian Chemistry, and the Folklore of the Ghost." Victorian Review 26.1 (2000): 6-23. Print. Herdman, John. The Double in Nineteenth-Century Fiction. Basingstoke: Macmillan, 1990.
Print.

Hoffmann, E.T.A. "The Sandman." 1817. The Golden Pot and Other Tales. Trans. Ritchie Robertson. Oxford: Oxford UP, 2006. 85-118. Print.

Krohn, Wolfgang, and Wolf Schäfer. "The Origins and Structure of Agricultural Chemistry." Perspectives on the Emergence of Scientific Disciplines. Ed. Gerard Lemaine et al. Paris: Mouton \& Co., 1976. 27-52. Print.

Ledger, Sally. "Christmas." Charles Dickens in Context. Ed. Sally Ledger and Holly Furneaux. Cambridge: Cambridge UP, 2011. 178-85. Print.

Dickens and the Popular Radical Imagination. Cambridge: Cambridge UP, 2007. Print. Miller, David Lee. Dreams of the Burning Child: Sacrificial Sons and the Father's Witness. Ithaca: Cornell UP, 2003. Print.

Miller, Karl. Doubles: Studies in Literary History. Oxford: Oxford UP, 1985. Print.

McDonagh, Josephine. Child Murder and British Culture, 1720-1900. Cambridge: Cambridge UP, 2003. Print.

- "Child-Murder Narratives in George Eliot's Adam Bede: Embedded Histories and Fictional Representation." Nineteenth-Century Literature 56.2 (Sept. 2001): 228-59.
Print.

Nabokov, Vladimir. Despair. 1937. London: Penguin, 2010. Print.
O'Brien, Karen. "Jane Austen's : Bristol University, Bristol.

Pfau, Thomas. Wordsworth's Profess Production. Stanford: Stanfor Poe, Edgar Allan. "William Wils 1980. 79-96. Print.

Rank, Otto. The Double: A Psychoan North Carolina P, 1971. Pri Royle, Nicholas. The Uncanny. Ma Schad, John. The Reader in the Dickt 1992. Print.

Stevenson, Robert Louis. The Stra Luckhurst. Oxford: Oxford Thompson, F.M.L. "Lawes, Sir Jc of National Biography. 2004 .V

Vardoulakis, Dmitri. The Doppelgär Print.

Webber, Andrew. The Doppelgänger: 1996. Print. 
alchemist, ) split in two, Redlaw in the

\section{Man."}

s: Ohio UP,

New York: St.

): I-13. Web.

is Carol and Other

06. 323-408.

Ss, 1988. Print.

I5. Print.

idge Economic

e UP, 1965.

and The Double.

tor Person,

P. 2010. Print.

$\therefore$ Nineteenth-

1s. Yvonne

'glect':

'Victorian

n, 1990.

itchie

tural

maine et al.

Furneaux

2007. Print.

Ithaca:

ambridge

fistories

ग) : 228-59.
O'Brien, Karen. “Jane Austen's Surplus People." Bristol University. English Department, Bristol University, Bristol. 14 Jan. 2010. Tucker-Cruse Lecture.

Pfau, Thomas. Wordsworth's Professions: Form, Class, and the Logic of Early Romantic Cultural Production. Stanford: Stanford UP, 1997. Print.

Poe, Edgar Allan. "William Wilson." Selected Tales. Ed. Julian Symons. Oxford: Oxford UP, 1980. 79-96. Print.

Rank, Otto. The Double: A Psychoanalytic Study. Trans. Harry Tucker, Jr. Chapel Hill: U of North Carolina P, 1971. Print.

Royle, Nicholas. The Uncanny. Manchester: Manchester UP, 2003. Print.

Schad, John. The Reader in the Dickensian Mirrors: Some New Language. Basingstoke: Macmillan, 1992. Print.

Stevenson, Robert Louis. The Strange Case of Dr Jekyll and Mr Hyde and Other Tales. Ed. Roger Luckhurst. Oxford: Oxford UP, 2008. I-66. Print.

Thompson, F.M.L. "Lawes, Sir John Bennet, First Baronet ( $1814-1900)$." Oxford Dictionary of National Biography. 2004 . Web. 30 Mar. 2012.

Vardoulakis, Dmitri. The Doppelgänger: Literature's Philosophy. New York: Fordham UP, 2010. Print.

Webber, Andrew. The Doppelgänger: Double Visions in German Literature. Oxford: Oxford UP, 1996. Print. 